\title{
Toksik Liderlik Algısının Kariyer Bağlılı̆̆ı ve Görev Performansıyla İlişkisine Yönelik Perakendecilik Sektöründe Bir Araştırma
}

\author{
A Research On Retail Sector Related To The Relationship Of Toxic Leadership \\ Perception On Career Commitment And Task Performance
}

\author{
Mehmet Ali CANBOLAT * \\ Adnan CELIK ** \\ Hande ULUKAPI YILMAZ ***
}

\begin{abstract}
$\ddot{O} Z$
Karaman ilinde faaliyet gösteren iki farkl yerel perakende zincirinde çalışan personelin toksik liderlik algısının kariyer bağlllı̆̆ ve görev performansıyla ilişkisinin belirlenmesi amacıyla kesitsel tipte, tanımlayıcı ve ilişki arayıcıyı olarak planlanan bu araştırma 102 işgören üzerinde gerçekleştirilmiştir. Elde edilen veriler SPSS22 programında ortalama, standart sapma, en küçük ve en büyük değerler gibi tanımlayıcı istatistikler ve korelasyon analizleri ile teste tabi tutulmuştur. Araştırma bulgularına göre; toksik liderlik algısı ile kariyer bağlllı̆̆ ve görev performansı arasında anlamlı ilişki olmadı̆̆l; kariyer bağlılı̆̆ ile görev performansı arasında pozitif yönde anlamlı ilişki olduğu tespit edilmiştir. Aynı zamanda toksik liderlik, kariyer bağlılı̆̆ ve görev performansı ölçeklerinin demografik özelliklerden etkilenmediği elde edilen bir diğer bulgudur.
\end{abstract}

ANAHTAR KELIMELER

Toksik Liderlik, Kariyer Bağglılı̆̆l, Görev Performansı

\begin{abstract}
This research, which was planned as a descriptive and relation seeker survey in across-sectional type, was applied on a total of 102 employees, who were working in two different local retail chains in Karaman province, in order to determine the relationship of toxic leadership perception on career commitment and task performance. The data obtained were analyzed by using SPSS 22 program for descriptive statistics such as mean, standard deviation, minimum and maximum values, and correlation analyzes. According to research findings; it was found that there was no significant relationship among the toxic leadership scale, career commitment scale and task performance scale, and there is a positive correlation between career commitment scale and task performance scale. It is also another finding that toxic leadership, career commitment and task performance scales are not affected by demographic characteristics.
\end{abstract}

\section{KEYWORDS}

Toxic Leadership, Career Commitment, Task Performance

\begin{tabular}{|c|c|c|}
\hline \multicolumn{2}{|r|}{$\begin{array}{c}\text { Makale Geliş Tarihi / Submission Date } \\
18.07 .2020\end{array}$} & $\begin{array}{c}\text { Makale Kabul Tarihi / Date of Acceptance } \\
\text { 28.12. } 2020\end{array}$ \\
\hline Atıf & $\begin{array}{l}\text { Canbolat, M. A., Çelik, A. ve Uluka] } \\
\text { Performansıyla İlişkisine Yönelik Pe } \\
\text { Meslek Yüksekokulu Dergisi, } 24 \text { (1), } 2\end{array}$ & $\begin{array}{l}\text { Toksik Liderlik Algısının Kariyer Bağlılığı ve Görev } \\
\text { e Bir Araştırma. Selçuk Üniversitesi Sosyal Bilimler }\end{array}$ \\
\hline
\end{tabular}

\footnotetext{
* Öğr.Gör., Karamanoğlu Mehmetbey Üniversitesi, Sosyal Bilimler Meslek Yüksekokulu, mcanbolat@kmu.edu.tr, ORCID: 0000-0003-1235-9013

** Prof.Dr., Selçuk Üniversitesi, İktisadi ve İdari Bilimler Fakültesi, adnancelik@selcuk.edu.tr, ORCID: 0000-0002-8538-9937

*** Arş.Gör., Selçuk Üniversitesi, İktisadi ve İdari Bilimler Fakültesi, handeulukapi@selcuk.edu.tr, ORCID:0000-0001-7496-7095
} 


\section{GİRIŞ}

Özellikle ilksel besin kaynağı ve zaruri ihtiyaçlara yönelik ürün tedarikçisi konumunda yer alan perakende sektörü her kesimden milyonlarca tüketiciye hitap etmektedir. Mesai sürelerindeki düzensizlikler, stok ve fiyat bilgilerinin periyodik takip gerekliliği ve ürün son tüketim tarihlerinin göz önünde bulundurulması gibi iş süreçlerindeki ayrıntılar, sektörü yoğun iş temposu baskısı altına almaktadır. Bu baskı ortamı, örgüt koşullarından yada yöneticinin liderlik özellikleri gibi etkenlerden kaynaklanabilmektedir. Olumsuz ve etkisiz liderlik üzerine yapılan araştırmalar tüm ya da herhangi bir paydaşa zararlı olan davranışları kavramaya yöneliktir. Temel olarak olumsuz liderlik özellikleri ile ön plana çıkarak adından sıkça söz ettirmeye başlayan toksik liderlik kavramı ve işgörenlerin çalıştıkları örgütte bir gelecek planlamaları bağlamında kariyer bağlılıkları ile bilgi ve yeteneklerini sergileyebildikleri görev performansı konuları günümüzde tartış1lan başlıklar arasında yer almaktadır. Toksik liderliğin doğasında olumsuz tavırlarla astlara ve örgüte zarar verip, etrafını zehirleyen bir kişilik söz konusudur.

Toksik liderliğin kariyer bağlılığı ve görev performansıyla ilişkisine yönelik perakendecilik sektöründe bir araştırma başlıklı bu çalışma teorik ve araştırma kısımlarından oluşmuştur. Bu bağlamda çalışmada, öncelikle toksik liderlik, kariyer bağlılığı ve görev performansı kavramları arasındaki ilişki kuramsal çerçevede ortaya konulmaya çalışılmış, ardından perakende sektörü çalışanlarının yöneticileri üzerinde algıladıkları toksik liderlik özelliklerinin kariyer bağlılığı ve görev performansıyla olan ilişkisine yönelik saha araştırmasının bulgularına yer verilmiştir.

\section{KAVRAMSAL ÇERÇEVE}

Bu kısımda araştırmada kullanılan üç değişken (toksik liderlik, kariyer bağl1lığı ve görev performansı) ile ilgili alan yazından derlenen bilgilere yer verilmiştir.

\subsection{Toksik Liderlik}

Toksik liderlik kavramı ile ilgili alan yazında çeşitli tanımlar bulunmaktadır. Kötü niyetli denetim olan toksik liderlik, genel kabul görmüş bir tanım ile örgütte zorbalık şekli olarak kabul edilir (Williams, 2018:180). $\mathrm{Bu}$ kavrama göre karşımızda; bireysel çıkarlarını her şeyin üstünde gören, açık iletişimden kaçınan, statükoyu koruyarak gelişimi engelleyen, eleştiriye kapalı, güven tesis etmeyen, korku yayan, kriz ve strese yol açan, kısmen narsist ve de vizyonsuz bir lider tipi vardır (Goldman, 2011:151; Şimşek ve Çelik, 2018:64). Reyhanoğlu ve Akın (2016:445) toksik liderliği, "örgüt içinde çalışanlara olumsuz sonuçlar doğuran ve örgütün genel olarak performansını azaltan, olumsuz özelliklere sahip liderlik biçimi” olarak tanımlamışlardır. Örgütlerde yöneticiler tarafından uygulanan liderlik tipi, işgörenlerin örgüte olan bağl1lıkları, işten ayrılma niyetleri, kariyer bağlılıkları ya da görev performansı gibi birçok etken üzerinde önemli bir neden olabilmektedir (Yalçınsoy ve Işık, 2018:1016). Toksik, diğer bir ifade ile zehirli liderler, işgörenleri, çalışma ortamını ve örgüt iklimini olumsuzluğa yönelten ve örgüte zarar veren lider tipidir(Çelebi vd., 2015:252). Zehirli davranışlar bunlarla sınırlı olmamak üzere, korkutucu, zorbalık, hileyle yönlendirme, mikro yönetme, kibir ve küfürlü veya etik olmayan davranışlarda bulunmayı da içerir (Webster vd., 2016:346). Toksik liderler, etik olmayan davranışlarda bulunarak, kendi ihtiyaç ve hedeflerini ilk sıraya koymaktadırlar (Seago, 2016:29). Belirsizlik ve karmaşa ortamı yaratan toksik liderlerin (Watt vd., 2016:200) bugüne kadar kazanmış olduğu başarılar ise etik olmayan davranışlarının geri planda kalmasına destek vermektedir (Kırbaç, 2013:129).

Çelebi vd.'ne göre (2015) toksik liderliğin dört alt boyutundan söz etmek mümkündür. Bunlar; çıkarcılık, değer bilmezlik, olumsuz ruhsal durum ve bencilliktir. Buna göre toksik liderler, biz yerine ben demeyi tercih etmekte, kurumsal başarıların yalnızca kendisine, başarısızlıkların ise çalışanlara ait olduğunu (Çetinkaya, 2017:100) düşünmekte ve genellikle işgörenlerin daha fazla çalışmasını ve fedakârlık etmesini beklemektedirler (Schmidt, 2008:4). Bu sebepledir ki; çalışanlara, örgütlere ve müşterilere ciddi zarar verirler (Roter, 2011:34). Örgütün faaliyetleri, performansı ya da dinamikleri ile ilgili karar verme güçleri sayesinde örgütün verimliliği, işlevselliği, marka değeri ve örgüt kültürüne zarar verecek böylelikle örgütü uzun vadede maliyet doğuran zararlara maruz birakacaklardır (Vreja vd., 2016:225).

Toksik liderin, yönetim konusunda eğitimsiz ve deneyimsiz olması, daha çok gücün kullanılmasına, dolayısıyla da örgüt atmosferini bozmaya neden olacaktır (Çetinkaya, 2017:30). Ayrıca toksik lider, yıkıc1 veya işlevsiz karakteristik özellikleriyle, kendi örgütleri üzerinde, izleyenleri üzerinde hatta onun himayesinde olmayanlar üzerinde dahi ciddi ve dayanılmaz zararlar verebilme özelliklerine sahiptir (Kırbaç, 2013:64). Toksik liderler, sadece yüksek düzeyde talepleri olan, kibirli ya da sert ifadeli bir görünüme sahip kişilerden oluşmamakla birlikte yumuşak bir mizaca sahip, ağırbaşlı ya da aşırı samimiyet gösteren kişiler de rahatlıkla toksik liderlik özellikleri taşıyabilmektedir (Reed, 2004:67). 
Toksik liderlik özellikleri sergilenen örgütlerde bu durum hakkında gözle görülür çok az bir belirti olmasına rağmen örgütteki olumsuz sonuçları hızla yaygınlaşacaktır (Winn ve Dykes, 2019:39). Dolayısı ile örgütlerin toksik davranışları tanımlayabiliyor olması aynı zamanda bu olumsuzluğun giderilmesi için gerekli tedbirlerin alınması adına büyük önem arz etmektedir (Mehta ve Maheshwari, 2013:1-2).

\subsection{Kariyer Bağlılığı}

1970’ li yıllarda önemsenmeye başlanan (Öge, 2016:280) ve iş dünyasında ilerlemeye ve örgütsel hiyerarşide yukarı doğru yükselmeye elverişli işleri tanımlamada kullanılan kariyer (Çelik, 2016:129), bireyin çalışma hayatında ilerlemesi, gelişmesi, bilgi ve deneyim kazanmasıdır (Bedük, 2012:121). Kariyer bağl11ı̆̆ kavramı ise temelde; kişinin mesleğe veya mesleğe yönelik tutumu olarak tanımlanabilir (Blau, 1985:278). Nihayetinde işgörenler çalıştığı örgütteki koşullardan memnun olmasalar bile kariyerleri nedeni ile örgütte çalışmaya devam edebilirler (Özdevecioğlu ve Aktaş, 2007:3). Bu açıdan bakıldığında ise kariyer bağlılı̆̆ı; işgörenin, işe olan bağlılı̆̆ı, kariyer hedefleri belirliyor olması ve bu hedeflere dâhil olma gibi mesleğine yönelik tüm olumlu tutumlarını içermektedir (Azim ve Islam, 2018:4).

Kariyer bağlılığı; işgörenlerin, kariyer yolundaki çalışma motivasyonu (Carson ve Bedeian, 1994:238; İnan, 2017:190; Jue ve Ha, 2018:28) ve kariyeri doğrultusundaki davranışlarıdır (Onay, 2016:13).Kariyer bağlılı̆̆1, işgörenin mesleğiyle özdeşleşmesi ve buna dâhil olması ile ilgilidir (Wickramasinghe, 2016:410). Daha az kariyer bağlılığı gösteren bir işgören, kariyer hedeflerine ulaşmak yerine kariyer değişikliği yapmaya meyillidir (Colarelli ve Bishop, 1990:159). Oysa yetenekli işgörenlerin kariyerlerine olan bağl1lıkları örgütte kalıcılıkları açısından son derece önemlidir (Afsar vd., 2019:6).

Son yıllarda yapılan araştırmalar incelendiğinde; öznel iyi olmanın, psikolojik sermaye ve kariyer bağl1lı̆̆ ilişkisine kısmen aracılık ettiği (Singhal and Rastogi, 2017:469), kariyer bağl1lı̆̆ının, ücret, terfi, statü ve kariyer tatminini pozitif yönde ve anlamlı olarak etkilediği (Otluoğlu, 2014:359), iş memnuniyeti ile kariyer bağlılı̆̆ının işten ayrılma niyeti üzerinde doğrudan pozitif yönde bir etkisinin olduğu (Gümüşsoy, 2016:19), işgörenlerin kariyer bağlılıklarının kariyer tahminlerini anlamlı ve doğrusal yönde etkilediği (Kendir ve Özkoç, 2018:98) ve işgörenlerin temel pskolojik ihtiyaçlarının karşılanması durumunda kariyer bağl1lıklarının da arttığ1 (Onyishi vd., 2019:477) görülmüştür.

\subsection{Görev Performansı}

Görev performansı kavramı ise "şekilsel iş tanımları kapsamında ana dönüşümlerin gerçekleştirilmesi ve eylemlerin yerine getirilmesine yönelik bir performans türüdür" (Tunca, 2018:42). Görev performans1; "işgörenlerin, görev ya da görevleri doğrultusunda resmi zorunluluk olarak sergilemiş oldukları davranışlar" (Günaydın, 2018:71), üstlendikleri iş yükümlülükleri kapsamında sergiledikleri çabalar bütünü (Borman ve Motowidlo, 1997:99-100) ve üstlenilen sorumlulukların ifa edilmesidir (Murphy, 1989:185). Campbell (1999)'a göre ise işgörenin bilgi, yetenek ve motivasyonunun belirlenmiş olan iş tanımlarına yönlendirilmesi olup (Aktaran: Şahin ve Gürbüz,2012:134) işgörenin yapması gereken görevleri yerine getirirken verimli, etkin ve daha yüksek kalitede iş üretmesi anlamına gelir (Sun vd., 2019:403).

Görev performansı, "bir işin ustalık ve mesleki yönüyle ilgili olan, resmi iş tanımları kapsamı çerçevesinde değerlendirilen faaliyetlerin yerine getirilmesi ile ilgilidir" (Güğerçin, 2015:78). Bir işgörenin görev performans1, üstleri tarafından rahatlıkla gözlemlenebilmelidir (Gürbüz ve Ayhan, 2017:4).Görev performans1, üretilen mal ve hizmetlerde direkt olarak ilişkili iken teknik süreçlerde ise endirekt bir şekilde destekleyici rol oynamaktadır (İbrahimoğlu ve Aydınçelebi, 2013:255).

Xia ve arkadaşları (2019:353) araştırmalarında örgütsel dışlanmışlığın fiziksel ve duygusal enerjiyle olumsuz yönde ilişkili olduğunu ve bu durumun da görev performansını düşürdügünü tespit etmişlerdir. Kirmani ve arkadaşları (2019:401) ise düşük düzeyde başarıya sahip işgörenlerin aynı zamanda görev performanslarının da düşük olduğu bulgusuna ulaşmışlardır. Ayrıca iş tatmininin, görev performansları üzerinde pozitif yönde anlamlı bir etkisinin olduğu (Yorulmaz, 2018:359), görev performansının genel özyeterliliği etkilediği (Howard, 2019:645), çalışma ortamı özelliklerinin görev performansı algısı üzerinde etkili olduğu (Akca, 2017:204) ve işgörenlerin algıladıkları görev yönelimli liderliğin görev performansları üzerinde pozitif etkisinin olduğu (Özdevecioğlu ve Kanıür, 2009:77) araştırmacıların bulguları arasındadır.

\subsection{Toksik Liderlik ile Kariyer Bağlılığı ve Görev Performansı İlişkisi}

Liderliğin bireylerin verimlilikleri üzerindeki olumlu etkilerine yönelen çalışmaların yanında, bazı diğer liderlerin bunun tam tersi yönde hareket ettikleri bir gerçektir (Reyhanoğlu, ve Akın, 2016:444). Toksik liderler bu kategoride sayllabilmektedirler. Harris vd. (2007:278) toksik liderlerin işlerini daha anlamlı bulan ve daha güçlü bir bağlılık hisseden astları için daha tehlikeli olduklarını savunmuşlardır. Bu şekilde işlerini anlamlı 
bulan bireylerin kariyerlerine bağlı bireyler olacakları düşünülmektedir. Behery vd. (2018:807) de toksik liderlerin bireylerin bağl1lıklanı üzerinde etkisi olduğundan bahsetmişlerdir. Literatürde toksik liderliğin örgütsel bağlılık ile ilişkisini ele alan çalışmalar olmakla birlikte bu çalışmada toksik liderliğin kariyer bağlılığı ile ilişkisi araştırma konusu edilmiş, bu doğrultuda $\mathrm{H}_{1}$ hipotezi aşağıdaki şekilde kurulmuştur.

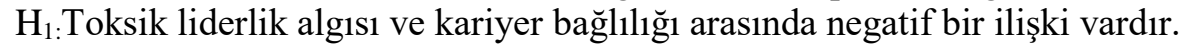

Toksik liderliğin alt boyutlarının kariyer bağlılığı ile ilişkisini belirlemek amacıyla ise aşağıdaki alt hipotezler kurulmuştur.

$\mathrm{H}_{1 \mathrm{a}}$ Değer bilmezlik ve kariyer bağl1lı̆̆ arasında negatif bir ilişki vardır.

$\mathrm{H}_{1 \mathrm{~b}}$ : Çıkarcılık ve kariyer bağ $\operatorname{lil}_{\mathrm{g}} \mathrm{g}$ arasında negatif bir ilişki vardır.

$\mathrm{H}_{1 \mathrm{c}}$ Bencillik ve kariyer bağlılığı arasında negatif bir ilişki vardır.

$\mathrm{H}_{1 \mathrm{~d}}$ Olumsuz ruhsal durum ve kariyer bağlılığı arasında negatif bir ilişki vardır.

Performans bir örgütte yöneticilerin en önemli gördükleri çıtılardan birisidir. Öyle ki bireylerin performanslarının yöneticilerinin sergiledikleri liderlik ile yakından ilişkili olduğu düşünülmektedir (Korkmaz, 2005:406). Liderin davranışları ile bireylerin performansı arasında bir ilişki olup olmadığına dair araştırmalar Kurt Lewin ve arkadaşlarının Iowa Üniversitesi çalışmalarına kadar dayanmaktadır (Akbaba ve Erenler, 2008:24). Toksik liderlik algısının da bireyin performansı ile ilişkili olduğu literatürde yer alan bulgular içerisindedir (Pelletier, 2010:386). Öz saygılarına saldıran toksik liderlere maruz kalan bireyler, performanslarında kötüye gitme eğilimindedirler (Kusy ve Holloway, 2009:27).Örneğin, Lipman-Blumen (2005:7) de toksik liderliğin en belirgin sonuçları arasında bireyin performansı ve bağlılığındaki düşüşe vurguda bulunmuştur. Bu bilgiler 1şığında toksik liderliğin bireyi ruhsal açıdan olumsuz etkileyebileceği düşünülmüş ve $\mathrm{H}_{2}$ hipotezi kurulmuştur.

$\mathrm{H}_{2}$ : Toksik liderlik algısı ve görev performansı arasında negatif bir ilişki vardır.

Toksik liderliğin alt boyutlarının görev performansı ile ilişkisini belirlemek amacıyla ise aşağıdaki alt hipotezler kurulmuştur.

$\mathrm{H}_{2 \mathrm{a}}$ : Değer bilmezlik ve görev performansı arasında negatif bir ilişki vardır.

$\mathrm{H}_{2 \mathrm{~b}}$ : Çıkarcılık ve görev performansı arasında negatif bir ilişki vardır.

$\mathrm{H}_{2 \mathrm{c}}$ Bencillik ve görev performansı arasında negatif bir ilişki vardır.

$\mathrm{H}_{2 \mathrm{~d}}$ Olumsuz ruhsal durum ve görev performansı arasında negatif bir ilişki vardır.

Bireyin kariyerine karşı tutumunun kariyer bağl1lığına işaret ettiği düşünüldüğünde (Chang, 1999:1258),kariyerlerine bağlı bireylerin hedeflerine ulaşabilmek için karşlaşabilecekleri engelleri aşma konusunda daha fazla gayret sarf edeceklerini savunan Özdevecioğlu ve Aktaş (2007:3), kariyer bağlılığının yüksek düzeyde hissedilmesi ile görev performansının artacağını belirtmişlerdir. Bu doğrultuda kariyer bağlılı̆g ile görev performansı arasındaki ilişkiyi test etmek amacıyla aşağıdaki hipotez kurulmuştur.

$\mathrm{H}_{3}$ : Kariyer bağl1lı̆̆ ve görev performansı arasında pozitif bir ilişki vardır.

Kurulan hipotezlerden hareketle araştırmanın modeli Şekil 1'deki gibi oluşturulmuştur.

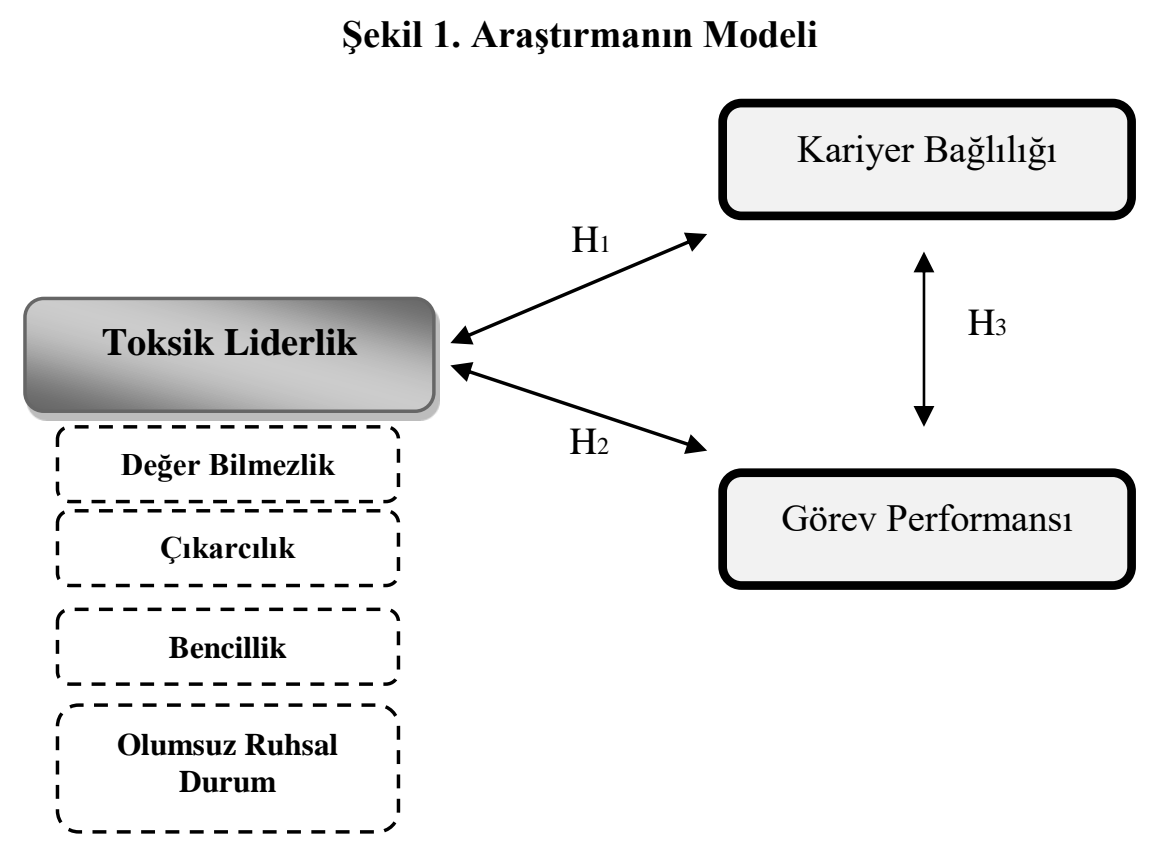

Selçuk Üniversitesi Sosyal Bilimler Meslek Yüksekokulu Dergisi, Yıl: 2021 Cilt: 24 Sayı:1 


\section{ARASTTIRMANIN METODOLOJISİ}

\subsection{Araştırmanın Problemi, Amacı ve Önemi}

Bu çalışmanın sorusu "Toksik liderlik algısının, kariyer bağlılı̆̆ı ve görev performansı arasında ilişki var mıdır?"olarak belirlenmiştir. Araştırmanın temel problemini, katılımcıların yöneticilerinden algıladıkları toksik liderlik özelliklerinin kariyer bağlılıkları ve görev performanslarıyla olası ilişkisinin varlığ oluşturmaktadır.Bu doğrultuda araştırmada, perakende sektörü çalışanlarının, yöneticilerinde algıladıkları toksik liderlik düzeylerinin, kariyer bağlılıkları ve görev performanslarıyla olan ilişkisinin tespit edilmesi amaçlanmıştır. Alan yazında toksik liderlik kavramı ile ilgili birçok araştırma yapılmış olmasına rağmen, bu kavramın kariyer bağlılı̆̆ ve görev performansıyla ilişkisini ölçmeye yönelik bir araştırmaya rastlanılmamıştır. Araştırma bu yönü ile ulusal alan yazına katkı sağlaması bakımından önemlidir.

$\mathrm{Bu}$ çalışmanın alt sorusunu ise "Kariyer bağllığı görev performansı ile ilişkili midir?" sorusu oluşturmaktadır. Problemi ise kariyer bağlılığı ve görev performansı arasında bir ilişkinin olup olmadığıdır. $\mathrm{Bu}$ doğrultuda araştırmanın alt amacını perakende sektörü çalışanlarının kariyer bağlılıklarının görev performansı ile ilişkisini ortaya koymak oluşturmaktadır.

\subsection{Araştırmanın Yöntemi}

Araştırma, Karaman ilinde faaliyet gösteren en çok şube sayısına sahip iki farklı yerel perakende zincirinde çalışan personelin toksik liderlik algısının kariyer bağlılıkları ve görev performanslarıyla olası ilişkisinin belirlenmesi amacıyla kesitsel tipte, tanımlayıcı ve ilişki arayıcı olarak planlanmıştır. Araştırmada veri toplama araçlarından bir tanesi olan anket yönteminden yararlanılmıştır. Veri toplama formunda ilk olarak demografik bilgileri içeren 6 soru, ikinci bölümde Colarelli ve Bishop (1990) tarafından geliştirilen ve Özdevecioğlu ve Aktaş (2007)' in çalışmalarında kullandıkları kariyer bağlılığı ölçeği (17 soru), üçüncü bölümde Schmidt (2008) tarafından geliştirilen Çelebi ve arkadaşlarının (2015) kullandıkları değer bilmezlik (11 madde), çıkarcılık (9 madde), bencillik ( 5 madde) ve olumsuz ruhsal durum (5 madde) olmak üzere dört alt boyuttan oluşan toksik liderlik ölçeği (30 soru) ve son bölümde Borman ve Motowidlo (1993) tarafından geliştirilen, İbrahimoğlu ve Aydınçelebi (2013)'nin çalışmalarında kullandıkları görev performansı ölçeği (4 soru) uygulanmıştır. Ölçekler beşli likert ölçeğinde 1 "Kesinlikle Katılmıyorum" ve 5 "Kesinlikle Katıllyorum" ifadelerine karşı1lı gelmektedir.

\subsection{Araştırmanın Kapsam ve Sınırlılıkları}

Perakende sektörü hakkında düzenli araştırmalar yapan AC Nielsen Zet (Duman ve Yağc1, 2006:88), üreticilerin ürünleri ile ilgili markalaşma çabaları, pazar potansiyeli, pazar payı ve markanın uluslararası erişimi gibi başlıklarda veriler toplayan bir danışmanlık (Çelik, 2006, 202) ve araştırma şirketidir (Arslan, 2010:13). Şirket, tüketim ve alışveriş göstergelerine yönelik raporlar da sunmaktadır (Çat1, 2007:152).

Procter\&Gamble (Alo, Fairy, İpana, Prima), Unilever (Knorr, Lipton, Algida, Domestos, Omo), Eczacıbaş1 (Selpak, Solo, Unibaby), Hayat Kimya (Molfix, Bingo, Papia) ve Henkel (Persil, Vernel) gibi perakende sektörünün ana tedarikçilerinden olan dünya devleri pazar durumu hakkındaki güncel bilgileri ve tüketici eğilimleri hakkındaki raporları AC Nielsen Zet şirketinden temin etmektedirler. AC Nielsen Zet şirketi ise yerel zincirlerden en çok reyon, marka, müşteri, raf ve ürün çeşitliliğine sahip süpermarketler ile yaptı̆̆ 1 anlaşmalar sonucunda veri tedariki yapmaktadır. AC Nielsen Zet'in perakende ölçüm hizmetleri, pek çok perakende kanalından derlenen bilgilere dayanarak ürün satışlarının sürekli takibini sağladığından müşterileri için satış, pazar payları, dağıtım, fiyatlandırma, alan ve raf yönetimi ve promosyon aktiviteleri gibi konularda detaylı bilgi sağlayabilmektedir (Koçaş, vd., 2008:3).

Buradan hareketle araştırma, Karaman ilinde faaliyet gösteren en çok personel, raf, ürün çeşitliliği, marka, müşteri ve şubeye sahip iki farklı yerel perakende zincirinde çalışan kadrolu personel ile yürütülmüştür. Bu firmalar aynı zamanda AC Nielsen Zet şirketinin veri tedarik anlaşması yaptığı yerel perakende zincirleridir. Bu iki perakende zinciri çalışanlarının anakütle olarak ele alınmasının en önemli nedeni yoğun bir iş temposuna sahip olmalarından kaynaklanmaktadır. Aynı zamanda gözlem ve birebir görüşmeler yoluyla toksik liderliğe ait görüşler de elde edilmiştir. Her iki işletmede çalışan 140 kişi anakütle olarak ele alınmış olup \%95 güvenilirlik ve $\% 5$ hata payı ile örneklem 102 kişi olarak hesaplamıştır. Veriler Kasım-Aralık 2018 tarihleri arasında elde edilmiştir. Anket formu araştırmacı tarafindan yüz yüze görüşme yöntemi ile toplanmıştır. Elde edilen veriler SPSS22 programında say1, yüzde, ortalama, standart sapma, en küçük, en büyük değerler gibi tanımlayıcı istatistikler ve korelasyon analizleri ile teste tabi tutulmuştur. Araştırma, Karaman ilinde faaliyet gösteren en çok şube sayısına sahip iki farklı yerel perakende zincirinde araştırma tarihleri arasında aktif olarak çalışan ve araştırmaya katılmaya gönüllü personelle sınırlıdır. 


\subsection{Araştırmanın Bulguları}

Katılımcıların demografik özelliklerine ait bulgular Tablo 1'de verilmiştir. Buna göre katılımcıların \%53,9'u 21-30 yaş arasında, \%53,9'u kadın, \%48'i lise mezunu, \%68,6'sı bekâr, \%67,6'sı 0-5 yıl arasında iş tecrübesine sahip ve $\% 27,5$ 'i reyon görevlisi olarak çalışmaktadır.

Tablo 1. Katılımcıların Demografik Özellikleri

\begin{tabular}{|c|c|c|}
\hline & Demografik Özellikler & Sayı (\%) \\
\hline \multirow{4}{*}{ Yaş } & 20 ve aşağ $1 S 1$ & $14(13,7)$ \\
\hline & 21- 30 yaş & $55(53,9)$ \\
\hline & $31-40$ yaş & $23(22,5)$ \\
\hline & 41 yaş ve üzeri & $10(9,8)$ \\
\hline \multirow{2}{*}{ Cinsiyet } & Kadın & $55(53,9)$ \\
\hline & Erkek & $47(46,1)$ \\
\hline \multirow{3}{*}{ Ĕgitim Durumu } & İlköğretim & $20(19,6)$ \\
\hline & Lise & $49(48,0)$ \\
\hline & Üniversite & $33(32,4)$ \\
\hline \multirow{2}{*}{ Medeni Durum } & Evli & $32(31,4)$ \\
\hline & Bekâr & $70(68,6)$ \\
\hline \multirow{3}{*}{ İş Tecrübesi } & $0-5$ y1l & $69(67,6)$ \\
\hline & 6-10 y1l & $20(19,6)$ \\
\hline & 11 yıl ve üzeri & $13(12,7)$ \\
\hline \multirow{5}{*}{$\begin{array}{l}\text { Çalışılan } \\
\text { Departman }\end{array}$} & Kasa & $23(22,5)$ \\
\hline & Reyon & $28(27,5)$ \\
\hline & Depo & $13(12,7)$ \\
\hline & İdari & $19(18,6)$ \\
\hline & Diğer & $19(18,6)$ \\
\hline
\end{tabular}

Katılımcıların toksik liderlik toplam/alt boyutlardan, kariyer bağlılığı ve görev performansı ölçeklerinden aldıkları en küçük en büyük puanlar, ortalamalar, standart sapmalar ve cronbach alpha değerleri Tablo 2'de verilmiştir.

Tablo 2. Katılımcıların Toksik Liderlik Toplam/Alt Boyutları, Kariyer Bağlılı̆̆ı ve Görev Performansı Ölçeklerinden Aldıkları En Küçük En Büyük Puanlar, Ortalama ve Standart Sapma Değerler

\begin{tabular}{|lcccc|}
\hline \multicolumn{1}{|c}{ Ölçek/Alt Boyutlar } & Ortalama & Standart Sapma & $\begin{array}{c}\text { En Küçük- } \\
\text { En Büyük Değer }\end{array}$ & $\begin{array}{c}\text { Cronbach } \\
\text { Alpha }\end{array}$ \\
\hline Toksik Liderlik & 1,86 & 0,651 & $1-3,97$ & 0,94 \\
\hline Değger Bilmezlik & 1,78 & 0,718 & $1-4,36$ & 0,91 \\
\hline Çıarcıllk & 1,67 & 0,722 & $1-4,11$ & 0,93 \\
\hline Bencillik & 2,27 & 0,875 & $1-4,40$ & 0,77 \\
\hline Olumsuz Ruhsal Durum & 2,00 & 0,967 & $1-5$ & 0,89 \\
\hline Kariyer Bağlılı̆ı & 3,22 & 0,511 & $1,35-4,76$ & 0,72 \\
\hline Görev Performansı & 3,83 & 1,12 & $1-5$ & 0,92 \\
\hline
\end{tabular}

Ölçeklerin güvenilirliklerini gösteren cronbach alpha değerleri toksik liderlik için 0,94, kariyer bağlılı̆̆ için 0,72 ve görev performansı için 0,92 'dir. Ölçeklerin güvenilir sayılabilmesi ve analizlerin yapılabilmesi için bu değerlerin en az 0,70 olması gerekmektedir (Gürbüz ve Şahin, 2016: 325). Bu değerler ölçeklerin güvenilir olduğunu ve analizlere devam edilebileceğini göstermektedir.

Ortalamalar ise toksik liderlik için 1,86, kariyer bağl1lı̆̆ için 3,22 ve görev performans için 3,83 olarak elde edilmiş olup; 5'li Likert ölçeğinde söz konusu ortalama puanlar "1,00-2,33" düşük düzey, "2,34-3,66" orta düzey ve "3,67-5,00" yüksek düzey olarak değerlendirildiğinde; katılımcılar toksik liderliği düşük, kariyer bağlılığını orta ve görev performansını yüksek düzeyde algılamışlardır. 
Katılımcıların yaş, eğitim durumu, iş tecrübesi ve çalıştıkları bölüm ile toksik liderlik toplam/alt boyut, kariyer bağ lılı̆̆ ve görev performansı ölçeklerinden aldıkları puan ortalamalarının karşılaştırmaları Ek A'da verilmiştir. Buna göre; yaş, eğitim durumu, iş tecrübesi ve çalıştıkları bölüm ile toksik liderlik toplam/alt boyut, kariyer bağlılı̆g 1 ve görev performansı ölçeklerinden aldıkların puan ortalamaları açısından anlamlı farklılık olmadığı belirlenmiştir ( $\mathrm{p}>0.05)$.

Katılımcıların cinsiyet ve medeni durumları ile toksik liderlik toplam/alt boyut, kariyer bağlılı̆ı ve görev performansı ölçeklerinden aldıkları puan ortalamalarının karşılaştırmaları Ek B'de verilmiştir. Buna göre; erkeklerin kariyer bağlılığı puanı $(x=56,91 \pm 8,02)$,kadınlara $(x=52,73 \pm 8,84)$ oranla daha yüksek olduğu ve söz konusu farkın istatistiksel olarak anlamlı olduğu $(t=-2,506, p=0,014<0,05)$ belirlenmiştir. Diğer ölçeklerden alınan puan ortalamaları ile cinsiyet ve medeni durum arasında anlamlı farklılık bulunmamıştır ( $\mathrm{p}>0.05)$.

Katılımcıların toksik liderlik ölçeği toplam/alt boyutları, kariyer bağlılığı ve görev performansı ölçeklerinden aldıkları puan ortalamalarının korelasyonu Tablo 3’te verilmiştir.

Tablo 3. Katılımcıların Toksik Liderlik Ölçeği, Kariyer Bağlılığı ve Görev Performansı Ölçeklerinden Aldıkları Puanların Korelasyonu (n=102)

\begin{tabular}{|c|c|c|c|c|c|c|c|c|}
\hline & & 1 & 2 & 3 & 4 & 5 & 6 & 7 \\
\hline \multirow{2}{*}{$\begin{array}{c}\text { Toksik } \\
\text { Liderlik }\end{array}$} & Pearson Kor. & 1 & & & & & & \\
\hline & $\mathrm{p}$ & & & & & & & \\
\hline \multirow{2}{*}{ Dĕger Bilmezlik } & Pearson Kor. &, $919^{* * *}$ & 1 & & & & & \\
\hline & $\mathrm{p}$ &, 000 & & & & & & \\
\hline \multirow{2}{*}{ Çıkarcılık } & Pearson Kor. & ,893** &, $822^{* *}$ & 1 & & & & \\
\hline & $\mathrm{p}$ &, 000 &, 000 & & & & & \\
\hline \multirow{2}{*}{ Bencillik } & Pearson Kor. & $629^{* * *}$ &, $391^{* *}$ & $428^{* * *}$ & 1 & & & \\
\hline & $\mathrm{p}$ &, 000 & ,000 &, 000 & & & & \\
\hline Olumsuz & Pearson Kor. &, $773^{* *}$ &, $625^{* *}$ &, $534^{* *}$ & $425^{* *}$ & 1 & & \\
\hline Ruhsal Durum & $\mathrm{p}$ &, 000 & ,000 & ,000 & ,000 & & & \\
\hline Kariyer & Pearson Kor. &, 013 & ,010 &,- 016 & ,014 & ,044 & 1 & \\
\hline Bağlılığı & $\mathrm{p}$ & ,899 & ,919 &, 872 & ,886 &, 663 & & \\
\hline Görev & Pearson Kor. &,- 010 & ,006 &,- 065 & ,088 &,- 044 &, $195^{*}$ & 1 \\
\hline Performansı & $\mathrm{p}$ & ,920 & ,949 &, 516 & ,379 & ,664 &, 050 & \\
\hline
\end{tabular}

Tablo 3'e göre, toksik liderlik ile kariyer bağl1lı̆̆ arasında istatistiksel bakımdan anlamlı bir ilişki bulunamamıştır $(\mathrm{r}=0,13 ; \mathrm{p}=0,899>0,05)$. Buna göre $\mathrm{H}_{1}$ hipotezi reddedilmiştir. Diğer yandan toksik liderliğin alt boyutları değer bilmezlik, çıkarcılık, bencillik ve olumsuz ruhsal durum ile kariyer bağlılığı arasında istatistiksel bakımdan anlamlı ilişkiler bulunamamıştır $(\mathrm{p}>0,05)$. Bu veriler doğrultusunda ise $\mathrm{H}_{1 \mathrm{a}}, \mathrm{H}_{1 \mathrm{~b}}, \mathrm{H}_{1 \mathrm{c}}$ ve $\mathrm{H}_{1 \mathrm{~d}}$ hipotezleri de reddedilmiştir.

Yine Tablo 3'e göre, toksik liderlik ile görev performansı arasında istatistiksel bakımdan anlamlı bir ilişki tespit edilememiştir $(\mathrm{r}=-0,010 ; \mathrm{p}=0,920>0,05)$. Bu bulguya göre $\mathrm{H}_{2}$ hipotezi reddedilmiştir. Bununla birlikte toksik liderliğin alt boyutları değer bilmezlik, çıkarcılık, bencillik ve olumsuz ruhsal durum ile görev performansı arasında istatistiksel bakımdan anlamlı ilişkiler bulunamamıştır $(\mathrm{p}>0,05)$. $\mathrm{Bu}$ veriler doğrultusunda ise $\mathrm{H}_{2 \mathrm{a}}, \mathrm{H}_{2 \mathrm{~b}}, \mathrm{H}_{2 \mathrm{c}}$ ve $\mathrm{H}_{2 \mathrm{~d}}$ hipotezleri de reddedilmiştir. Öte yandan kariyer bağl1lı̆̆ ile görev performansı arasında ise pozitif yönde anlamlı bir ilişki olduğu görülmüştür $(r=0,195 ; p=0,05)$. Bir diğer ifadeyle, kariyer bağl1lı̆̆1 arttıkça görev performans1 düzeyi de artmaktadır. Bu bulgu doğrultusunda $\mathrm{H}_{3}$ hipotezi kabul edilmiştir.

\section{SONUÇ}

Karaman ilinde faaliyet gösteren en fazla sayıda personel ve şubeye sahip iki yerel perakende zincirinde çalışan personelin toksik liderlik algıları, kariyer bağlılıkları ve görev performanslarının belirlenmesi amacıyla planlanan araştırmaya 102 kişi katılmıştır.

Araştırmada, katılımcıların \%53,9'u 21-30 yaş arasında, \%68,6'sı bekâr ve \%67,6's1 0-5 yıl arasında iş tecrübesine sahip oldukları saptanmıştır. Bu durum yoğun çalışma temposundan ötürü genellikle genç ve bekârların sektörde daha çok tutunabildiklerine işaret olabilir. Ayrıca iş tecrübesine bakıldığında ise sektörde personel devir hızının yüksek olduğu da söylenebilir.

Katılımcıların yaş, eğitim durumu, iş tecrübesi ve çalıştıkları bölüm değişkenleri ile toksik liderlik, kariyer bağl1lı̆̆ ve görev performansı ölçeklerinden aldıkları puan ortalamaları arasında anlamlı farklılık olmadığı 
saptanmıştır. Bu durum Çetinkaya (2017:101)'nın değer bilmezlik, çıkarcılık, bencillik, olumsuz ruh hali ve toksik liderliğin genelinde yaşa göre anlamlı bir fark bulunmadığı iddiası ile örtüşmektedir. Özer ve arkadaşları (2017:18) ise bir kamu hastanesinde yürüttükleri araştırmalarında; orta yaş grubundaki çalışanların toksik liderlik algıların daha yüksek olduğu, yaş ilerledikçe toksik liderlik algısının azaldığı sonucuna ulaşmışlardır. $\mathrm{Bu}$ farklılık araştırma yapılan örgütlerin kamu ve özel sektör ayrımından yada sektör farklılı̆̆ından kaynaklanmış olabilir.

Ayrıca erkeklerin kariyer bağlılığı puanlarının kadınlara oranla daha yüksek puan olduğu ve farkın istatistiksel olarak anlamlı olduğu belirlenmiştir. Bu durum Zanardelli ve arkadaşlarının (2016:162) erkekler ile kadınlar arasında kariyer bağlılığı algısında farklılık olduğunu ileri sürdüğ̈ araştırmasıyla desteklenmektedir. Ek olarak toksik liderlik ve görev performansı ölçeklerinden alınan puan ortalamaları ile cinsiyet ve medeni durum arasında anlamlı farklılık bulunmadığ tespit edilen bulgular arasındadır.

Kariyer bağl1lı̆̆ 1 ile görev performansı arasında pozitif yönde anlamlı ilişki olduğu saptanan bir diğer bulgudur. Bu durum işgörenlerin kariyer bağlılıkları arttıkça görev performanslarının da artacağına işarettir. Toksik liderlik ölçeği ile kariyer bağlılığ ve görev performansı ölçeği arasında ise anlamlı ilişki olmadığ1 belirlenmiştir. Özdevecioğlu ve Aktaş (2007:3) ise kariyer bağlllı̆̆ olan bireylerin çalıştıkları koşul ve kişilerden bağımsız olduklarını çalışmalarında ileri sürmüşlerdir. Buna göre örgütünden ya da liderinden memnun olmayan işgörenlerin de kariyer bağlılıkları doğrultusunda beklenti ve hedef gözeterek yüksek performans sergileyebilecekleri söylenebilir.

Toksik liderliğin kariyer bağl1lı̆̆ ve görev performansıyla ilişkisine yönelik perakendecilik sektöründeki durumun ortaya konmasını hedefleyen bu çalışma sonucunda aşağıdaki önerilerde bulunulabilir:

-Perakende sektöründe; kadın çalışanların kariyer bağlılı̆̆ının artırılmasına yönelik eğitim programları oluşturulabilir, bu sayede işgörenlerin yaptığı işleri geçici görmesi yerine ilgili işte bir gelecek görmesinin önü açılmış olacaktır.

-İşörenlerin kariyer bağlılıkları arttıkça görev performansları da arttığından ötürü işgörenlere kariyer bağlılı̆̆ı sağlamak adına örgüt içi insan kaynakları uygulamaları geliştirilmelidir.

-Toksik liderlik davranışlarının perakende sektöründe kariyer bağlllığı ve görev performansına bir etkisinin olmadığı görülse de yeni araştırmaların toksik liderin bireyden ziyade örgüte zarar verdiği noktasından hareketle müşteri, tedarikçi, çözüm ortağ 1 vb. dış paydaşlarla gerçekleştirilmesi gerektiği önerilebilir. Ayrıca araştırmanın ileride yapılacak çalışmalar için yol gösterici bir nitelik taşıdığına ve benzer araştırmaların farklı il ve sektörlerde yapılarak kayda değer bulgular elde edileceğine inanılmaktadır. 


\section{KAYNAKÇA}

Afsar, Bilal, Umrani, Waheed Ali ve Khan, Awais (2019) "The impact of perceived calling on work outcomes in a nursing context: the role of career commitment and living one's calling", Journal of Applied Biobehavioral Research, 24(1), 1-18.

Akbaba, Atilla ve Erenler, Esra (2008) "Otel işletmelerinde yöneticilerin liderlik yönelimleri ve işletme performansı ilişkisi”, Anatolia: Turizm Araştırmaları Dergisi, 19(1), 21-36.

Akca, Meltem ve Yurtçu, Büşra Gizem (2017) "Çalışma ortamı özelliklerinin hekimlerin görev ve bağlamsal performansina etkisi", International Journal of Academic Value Studies, 3(15), 197-207.

Arslan, Eylem (2010) "Sinema reklamcılığı: sinema salonunun bir reklam mecrası olarak kullanımının Türkiye örneğinde incelenmesi”, İstanbul Üniversitesi İletişim Fakültesi Dergisi, 1(39), 5-27.

Azim, Mohammad, T. ve Islam, M. Mohammad M. (2018) "Social support, religious endersement, and career commitment: a study on Saudi nurses, Behavioral Sciences", 8(8), 1-13.

Bedük, Aykut (2012), Karşılaştırmalı İşletme-Yönetim Terimleri Sözlüğü, 3. bs., Nobel Yayınevi, Ankara.

Behery, Mohamed, Al-Nesser, Amjad, D., Jabeen, Fauziave El Rawas ve Ahmed, Said (2018) "Toxic leadership and organizational citizenship behavior: A mediation effect of followers' trust and commitment in the Middle East", International Journal of Business and Society, 19(3), 793-815.

Blau, Gary, J. (1985) "The measurement and prediction of career commitment”, Journal of Occupational Psychology, 58, 277-288.

Borman, Walter, C. ve Motowidlo, Stephan, J. (1997) "Task performance and contextual performance: the meaning for personnel selection research", Human Performance, 10(2), 99-109.

Carson, Kerry. D. ve Bedeian, Arthur, G. (1994) "Career commitment: construction of a measure and examination of its psychometric properties", Journal of Vocational Behavior, 44, 237-262.

Chang, Eunmi (1999) "Career commitment as a complex moderator of organizational commitment and turnover intention", Human Relations, 52(10), 1257-1278.

Colarelli, Stephen, M. ve Bishop, Ronald,C. (1990) "Career commitment functions, correlates, and management, Group \& Organization Studies", 15(2), 158-176.

Çatı, Kahraman, (2007) "Süpermarketlerin tercih edilmesinde etkili olan faktörlerin belirlenmesine yönelik bir araştırma", Elektronik Sosyal Bilimler Dergisi, 6(22), 150-168.

Çelebi, Nurhayat, Güner, Halim ve Yıldız, Veysel,(2015) “Toksik liderlik ölçeğinin geliştirilmesi”, Bartın Üniversitesi Eğitim Fakültesi Dergisi, 4(1), 249-268.

Çelik, Adnan, (2016) Kariyer Kavramı, Kapsamı ve Temel Boyutları. (içinde) İnsan Kaynakları Yönetimi ve Kariyer Uygulamaları, 3. bs., Ed. M.Ş. Şimşek, A. Çelik ve A. Akatay, Eğitim Kitabevi, Konya.

Çelik, Arzum, Erken, (2006) "Marka değerleme", Muhasebe ve Finansman Dergisi, (31), 195-208.

Çetinkaya, Hakan,(2017) "Okul Yöneticilerinin Toksik Liderlik Davranışları ile Öğretmenlerin Tükenmişlik Düzeyleri Arasındaki İlişki”, Yayımlanmamış Yüksek Lisans Tezi, Pamukkale Üniversitesi, Eğitim Bilimleri Enstitüsü, Denizli.

Duman, Teoman ve Yağc1, Mehmet, İsmail (2006) "Süpermarket müşterilerinin devamlı alışveriş niyetlerini etkileyen faktörler: Bir model denemesi”, ODTÜ Gelişme Dergisi, 33(1), 87-116.

Goldman, Alan, (2011) "Demagogue to dialogue-An alternative to toxic leadership in corporate downsizings", Organizational Dynamics, 40(3), 151-242.

Güğerçin, Utku, (2015) "Bireyin Etik Yaklaşımı ile Kurumsal Değerlerin Örgütsel Vatandaşlık Davranışı ve Görev Performansı Üzerindeki Etkisi: Adana İlindeki Banka Çalışanları Üzerine Bir Araştırma”, Yayımlanmamış Doktora Tezi, Çă̆ Üniversitesi, Sosyal Bilimler Enstitüsü, Mersin.

Gümüşsoy, Çiğdem, Altın (2016) "The effect of five-factor model of personality traits on turnover intention among information technology (IT) professionals", Online Academic Journal of Information Technology, 74(22), 7-28

Günaydın, Özge, Elmas, (2018) "Müşteri Odaklılık, İș Tatmini ve Görev Performansının Hizmet Telafi Performansı Üzerindeki Etkisi: Dış Ticaret Departmanı Çalışanlarına Yönelik Bir Araştırma”, Yayımlanmamış Yüksek Lisans Tezi, Muğla Sitkı Koçman Üniversitesi, Sosyal Bilimler Enstitüsü, Muğla.

Gürbüz, Sait ve Ayhan, Özgür, (2017) "Lidere yakın olmanın dayanılmaz hafifliği: lider-üye etkileşimi, görev performansı, tecrübe ve terfi edebilirlik arasındaki ilişkilerin testi”, Türk Psikoloji Dergisi, 32(80), 1-15.

Gürbüz, Sait ve Şahin, Faruk, (2016) Sosyal Bilimlerde Araştırma Teknikleri. 3. bs., Seçkin Yayıncıllk, Ankara.

Harris, Kenneth J., Kacmar, K. Michele, Zivnuska, Suzanneve Shaw ve Jason, D., (2007) "The impact of political skill on impression management effectiveness, Journal of Applied Psychology", 92, 278-285.

Howard, Matt, C., (2019) "Task performance influences general self-efficacy, even without increases in the skills required to achieve success", The Journal of Social Psychology, 159(5), 642-647.

İbrahimoğlu, Nurettin ve Aydınçelebi, Mihriban, (2013) "Kariyer bağlllığı ve öz-yetkinliğin görev performansına etkisi: sigortacılık sektöründe bir araştırma", AİBÜ Sosyal Bilimler Enstitüsü Dergisi, 13(2), 249-273.

İnan, İbrahim, (2017) "İş yükü algısı ve kariyer bağlılı̆̆ının örgütsel bağllık üzerine etkisi: beş yıldızlı otel çalışanları üzerine bir araştırma”, Ömer Halisdemir Üniversitesi, İktisadi ve İdari Bilimler Fakültesi Dergisi, 10(1), 184-198.

Jue, Julier ve Ha, Juhg, Hee, (2018) "The professional identity, career commitment and subjective well-being of art therapy students", The Arts in Psychotherapy, 57, 27-33. 
Kendir, Hakan ve Özkoç, Aziz, Gökhan, (2018) “Otel işletmelerinde çalışanların kariyer tatmini ve kariyer bağlılığı ilişkisinde öz yeterliliğin rolü”, Journal of Tourism and Gastronomy Studies, 6(4), 78-112.

Kırbaç, Merin,(2013) "Eğitim Örgütlerinde Toksik Liderlik”, Yayımlanmamış Yüksek Lisans Tezi, İnönü Üniversitesi, Eğitim Bilimleri Enstitüsü, Malatya.

Kirmani, Syeda, Shabana, Bakari, Haroon ve Irfan, Mahreen, (2019) "Role of core self evaluation and acquired motivations in employee task performance", Pakistan Journal of Psychological Research, 32 (2), 401-418.

Koçaş, Cenk, Irmak, Melek ve Duran, Yasin, (2008) "Pazarlama kararlarına pazarın verdiği tepkiler nasıl ölçülür?”, Pazarlama ve İletişim Kültürü Dergisi, 1-17.

Korkmaz, Mehmet, (2005) "Duyguların ve liderlik stillerinin öğretmenlerin performansı üzerindeki etkisi”, Kuram ve Uygulamada Eğitim Yönetimi, 43, 401-422.

Kusy, Mitchell ve Holloway, Elizabeth, (2009) Toxic Workplace: Managing Toxic Personalities and Their Systems of Power,Jossey-Bass, San Francisco.

Lipman-Blumen, Jean, (2005) "The allure of toxic leaders: Why followers rarely escape their clutches", Ivey Business Journal, 69(3), 1-40.

Mehta, Sunita ve Maheshwari, Girish, Chandra, (2013) "Consequence of toxic leadership on employee job satisfaction and organizational commitment”, The Journal Contemporary Management Research, 8(2), 1-23.

Murphy, Kevin, R., (1989) “Is the relationship between cognitive ability and job performance stable over time?", Human Performance, 2(3), 183-200.

Onay, Aynur, Özmutlu, (2016) "Kariyer Bağlılığı, Örgütsel Bağlılık ve İşten Ayrılma Eğilimi İlişkisi: Akademisyenler Üzerine Bir Uygulama”, Yayımlanmamış Yüksek Lisans Tezi, Kocaeli Üniversitesi, Sosyal Bilimler Enstitüsü, Kocaeli.

Onyishi, Ike, E., Enwereuzor, Ibeawuchi, K., Ogbonna, Martina, N. Ugwu, Fabian, O. ve Amazue, Lawrence, O., (2019) "Role of career satisfaction in basic psychological needs satisfaction and career commitment of nurses in Nigeria: a self-determination theory perspective", Journal of Nursing Scholarship. 51(4), 470-479.

Otluoğlu, K. Övgü, Çakmak, (2014) "Kariyer bağlılı̆̆ının kariyer başarısı üzerindeki etkisinin incelenmesi üzerine bir araştırma", Yönetim ve Ekonomi Araştırmaları Dergisi, 23, 350-363.

Öge, Serdar, (2016) İnsan Kaynakları Yönetimi, 8. bs., Eğitim Yayınevi, Konya.

Özdevecioğlu, Mahmut ve Aktaş, Aylin, (2007) "Kariyer bağlılığ1, mesleki bağl1lık ve örgütsel bağlılığın yaşam tatmini üzerindeki etkisi: iş-aile çatışmasının rolü”, Erciyes Üniversitesi İktisadi ve İdari Bilimler Fakültesi Dergisi, 28 , $1-20$.

Özdevecioğlu, Mahmut ve Kanıgür, Sevgi, (2009)“Çalışanların ilişki ve görev yönelimli liderlik algılamalarının performansları üzerindeki etkileri”, KMU İİBF Dergisi, (16), 53-82.

Özer, Özlem, Uğurluoğlu, Özgür, Kahraman, Gülcan ve Avci, Kezban, (2017) “A study on toxic leadership perceptions of healthcare workers", Global Business and Management Research: An International Journal, 9(1), 12-23.

Pelletier, Kathie, L., (2010) “Leader toxicity: An empirical investigation of toxic behavior and rhetoric”, Leadership, 6(4), 373-389.

Reed, George, E., (2004) “Toxic leadership”, Military Review, 84(4), 67-71.

Reyhanoğlu, Metin ve Akın, Özden, (2016) “Toksik liderlik örgütsel sağlığı olumsuz yönde tetikler mi?”, İnsan ve Toplum Bilimleri Araştırmaları Dergisi, 5(3), 442-459.

Roter, Annette, B., (2011) “The Lived Experiences Of Registered Nurses Exposed To Toxic Leadership Behaviors", Doctoral Thesis, Capella University, ABD.

Schmidt, Andrew, A., (2008) “Development And Validation Of The Toxic Leadership Scale", Master Thesis, University of Maryland, Faculty of the Graduate School, College Park, ABD.

Seago, Jane, (2016) "Toxic culture”, Internal Auditor, 73(3), 29-33.

Singhal, Hansika ve Rastogi, Renu, (2017) "Psychological capital and career commitment: the mediating effect of subjective well-being", Management Decision. 56(2), 458-473.

Sun, Heshan, Wright, Ryan, T. ve Thatcher, Jason, (2019) "Revisiting the 1mpact of system use on task performance: an exploitative-explorative system use framework", Journal of the Association for Information Systems, 20(4), 398433.

Şahin, Faruk ve Gürbüz, Sait, (2012) “Kültürel zekâ ve öz-yeterliliğin görev performansı ve örgütsel vatandaşlık davranış1 üzerinde etkisi: çokuluslu örgüt üzerinde bir uygulama", “İşGüç” Endüstri İlişkileri ve İnsan Kaynakları Dergisi, 14(2), 125-140.

Şimşek, M. Şerif ve Çelik, Adnan, (2018) Yönetim ve Organizasyon, 20. bs., Eğitim Yayınevi, Konya.

Tunca, Sezai, (2018) "Proaktif Kişilik Yapısının ve Yenilikçi Davranışın Görev Performansına Etkisi”. Yayımlanmamış Yüksek Lisans Tezi, Gebze Teknik Üniversitesi, Sosyal Bilimler Enstitüsü, Gebze.

Vreja, Lucia, Ovidia, Balan, Sergiu, Bosca, Loredana, Cornelia,(2016)“An evolutionary perspective on toxic leadership”, Management and Economics Review, 1(2), 217-228.

Watt, Steven,R., Javidi, Mitch ve Normore, Anthony, H., (2016) "Increasing darkness: combining toxic leadership and volatility, uncertainty, complexity, and ambiguity (VUCA)", In "The Dark Side of Leadership: Identifying and Overcoming Unethical Practice in Organizations", 26, 195-206.

Webster, Vicki, Brough, Paulave Daly, Kathleen, (2016) "Fight, flight or freeze: common responses for follower coping with toxic leadership", Stress and Health, 32, 346-354. 
Wickramasinghe, Vathsala, (2016) "The mediating effect of job stress in the relationship between work-related dimensions and career commitment", Journal of Health Organization and Management, 30(3), 408-420.

Williams, Kenneth,R., (2018) "Toxic leadership in defense and federal workplaces: sabotaging the mission and innovation", International Journal of Public Leadership, 14(3), 179-198.

Winn, Gary, L. ve Dykes, Ava, C., (2019) "Identifying toxic leadership \& building worker resilience", Professional Safety, 64(03), 38-45.

Xia, Aijing, Wang, Bin, Song, Baihe, Zhang, Wei ve Qian, Jing, (2019) "How and when workplace ostracism influences task performance: Through the lens of conservation of resource theory", Human Resource Management Journal, 29(3), 353-370.

Yalçınsoy, Ayhan ve Işık, Metin, (2018) “Toksik liderlik ile örgütsel bağlılık ve işten ayrılma niyeti ilişkisine yönelik bir araştırma”, Gaziantep University Journal of Social Sciences, 17(3), 1016-1025.

Yorulmaz, Murat, (2018) “Gemi adamlarının iş tatmini, görev ve bağlamsal performansları arasındaki ilişkiler”, Journal of ETA Maritime Science, 6(4), 349-363.

Zanardelli, Gina, Shivy, Victoria,A. ve Perrone-McGovern, Kristin,M., (2016) "Prodicting behavioral career commitment of collgege students with attachment and separation relationships", Journal of Employment Counseling, 53, 162 173. 


\section{EKLER}

Ek A: Yaş, Eğitim Durumu, İş Tecrübesi ve Kadro Türleri ile Toksik Liderlik Toplam/Alt Boyut, Kariyer Bağlılı̆ı ve Görev Performansı Ölçeklerinden Aldıkları Puan Ortalamalarının Karșılaștırmaları Tablosu

\begin{tabular}{|c|c|c|c|c|c|c|c|}
\hline $\begin{array}{l}\text { Ölçekler } \\
\text { Özellikler }\end{array}$ & $\begin{array}{c}\text { Toksik Liderlik } \\
\text { Ölçeği Toplam } \\
\text { Ort } \pm \text { SS }\end{array}$ & $\begin{array}{c}\text { Değer Bilmezlik } \\
\text { Ort } \pm \text { SS }\end{array}$ & $\begin{array}{c}\text { Çıkarcılık } \\
\text { Ort } \pm \text { SS }\end{array}$ & $\begin{array}{c}\text { Bencillik } \\
\text { Ort } \pm \text { SS }\end{array}$ & $\begin{array}{c}\text { Olumsuz Ruhsal } \\
\text { Durum } \\
\text { Ort } \pm \text { SS }\end{array}$ & $\begin{array}{c}\text { Kariyer Bağlılığ } \\
\text { Ölçeği } \\
\text { Ort } \pm \text { SS }\end{array}$ & $\begin{array}{c}\text { Görev Performansı } \\
\text { Ölçeği } \\
\text { Ort } \pm \text { SS }\end{array}$ \\
\hline \multicolumn{8}{|l|}{ Yaş } \\
\hline 20 yaş ve altı (14) & $52,21 \pm 16,75$ & $18,93 \pm 6,15$ & $15,14 \pm 5,30$ & $9,07 \pm 3,47$ & $9,07 \pm 3,51$ & $50,0 \pm 9,77$ & $14,21 \pm 5,23$ \\
\hline $21-30$ yaş (55) & $54,36 \pm 18,57$ & $18,80 \pm 7,65$ & $14,05 \pm 5,94$ & $11,73 \pm 4,31$ & $9,78 \pm 4,91$ & $55,25 \pm 8,52$ & $15,51 \pm 4,33$ \\
\hline 31-40 yaş (23) & $60,09 \pm 18,39$ & $21,17 \pm 7,54$ & $16,48 \pm 6,66$ & $11,78 \pm 4,39$ & $10,65 \pm 5,47$ & $55,70 \pm 7,24$ & $16,13 \pm 3,75$ \\
\hline 41 yaş ve üzeri (10) & $59,90 \pm 29,74$ & $20,60 \pm 11,93$ & $17,10 \pm 9,83$ & $11,40 \pm 5,40$ & $10,80 \pm 4,73$ & $55,50 \pm 10,30$ & $14,10 \pm 5,80$ \\
\hline $\mathbf{F} / \mathbf{p}$ & ,766/,516 & ,570/,636 & $1,139 /, 337$ & $1,501 /, 219$ &, $433 /, 730$ & $1,595 /, 196$ &, $808 /, 492$ \\
\hline \multicolumn{8}{|l|}{ Eğitim Durumu } \\
\hline İlköğretim (20) & $61,75 \pm 21,55$ & $21,10 \pm 9,03$ & $17,20 \pm 7,31$ & $12,70 \pm 4,54$ & $10,75 \pm 5,75$ & $54,75 \pm 10,94$ & $14,25 \pm 5,60$ \\
\hline Lise (49) & $54,84 \pm 19,04$ & $19,61 \pm 7,97$ & $14,63 \pm 6,60$ & $11,02 \pm 4,50$ & $9,57 \pm 4,32$ & $55,45 \pm 8,18$ & $15,51 \pm 4,24$ \\
\hline Üniversite (33) & $53,94 \pm 18,93$ & $18,45 \pm 7,08$ & $14,36 \pm 5,70$ & $11,00 \pm 4,03$ & $10,12 \pm 5,03$ & $53,42 \pm 8,02$ & $15,73 \pm 4,11$ \\
\hline $\mathbf{F} / \mathbf{p}$ & $1,138 /, 325$ & ,700/,499 & $1,391 /, 254$ & $1,203 /, 305$ & ,438/,646 &, $531 /, 589$ &, $745 /, 478$ \\
\hline \multicolumn{8}{|l|}{ İş Tecrübesi } \\
\hline $0-5$ y1l (69) & $56,20 \pm 18,32$ & $19,90 \pm 7,45$ & $15,30 \pm 6,25$ & $11,03 \pm 3,90$ & $9,97 \pm 4,78$ & $54,62 \pm 9,07$ & $14,71 \pm 4,75$ \\
\hline $6-10$ y1l (20) & $55,30 \pm 22,38$ & $18,95 \pm 9,05$ & $13,90 \pm 6,92$ & $12,55 \pm 5,76$ & $9,90 \pm 5,25$ & $54,15 \pm 6,98$ & $16,65 \pm 3,18$ \\
\hline 11 yıl ve üzeri (13) & $55,23 \pm 22,74$ & $18,46 \pm 8,78$ & $15,46 \pm 7,42$ & $11,15 \pm 4,33$ & $10,15 \pm 4,79$ & $55,62 \pm 9,50$ & $16,62 \pm 4,27$ \\
\hline $\mathbf{F} / \mathbf{p}$ & ,025/,975 &, $244 /, 784$ & ,388/,680 & ,951/,390 & ,011/,989 &, $112 /, 895$ & $2,103 /, 128$ \\
\hline \multicolumn{8}{|l|}{ Çalışılan Bölüm } \\
\hline Kasa (23) & $50,74 \pm 17,15$ & $18,04 \pm 6,87$ & $12,87 \pm 4,50$ & $10,39 \pm 4,54$ & $9,43 \pm 5,36$ & $53,04 \pm 9,35$ & $13,83 \pm 6,13$ \\
\hline Reyon (28) & $59,29 \pm 19,84$ & $19,75 \pm 8,16$ & $16,00 \pm 6,51$ & $12,14 \pm 4,23$ & $11,39 \pm 5,63$ & $55,93 \pm 8,34$ & $16,00 \pm 3,83$ \\
\hline Depo (13) & $55,31 \pm 15,15$ & $20,62 \pm 7,98$ & $14,38 \pm 6,57$ & $11,54 \pm 3,25$ & $8,77 \pm 2,48$ & $54,92 \pm 9,81$ & $15,31 \pm 5,13$ \\
\hline İdari (19) & $60,11 \pm 22,05$ & $21,00 \pm 7,67$ & $16,68 \pm 7,78$ & $11,68 \pm 4,54$ & $10,74 \pm 5,10$ & $57,47 \pm 5,42$ & $15,63 \pm 2,14$ \\
\hline Diğer (41) & $53,37 \pm 21,80$ & $18,79 \pm 9,16$ & $15,11 \pm 6,94$ & $10,84 \pm 4,99$ & $8,63 \pm 3,30$ & $51,74 \pm 9,77$ & $15,89 \pm 4,31$ \\
\hline $\mathbf{F} / \mathbf{p}$ & ,911/,461 & ,467 / ,760 & $1,139 /, 343$ & 667, 595 & $1,383 /, 246$ & $1,408 /, 237$ & ,895 / ,470 \\
\hline
\end{tabular}

Selçuk Üniversitesi Sosyal Bilimler Meslek Yüksekokulu Dergisi, Yıl: 2021 Cilt: 24 Sayı:1 
Ek B: Cinsiyet ve Medeni Durumları ile Toksik Liderlik Toplam/Alt Boyut, Kariyer Bağlılığı ve Görev Performansı Ölçeklerinden Aldıkların Puan Ortalamalarının Karşılaştırmaları ( $(\mathrm{N}=102)$ Tablosu

\begin{tabular}{|c|c|c|c|c|c|c|c|}
\hline $\begin{array}{l}\text { Ölçekler } \\
\text { Özellikler }\end{array}$ & $\begin{array}{l}\text { Toksik Liderlik } \\
\text { Ölçeği Toplam } \\
\quad \text { Ort } \pm \text { SS }\end{array}$ & $\begin{array}{c}\text { Değer Bilmezlik } \\
\text { Ort } \pm \text { SS }\end{array}$ & $\begin{array}{c}\text { Çıkarcılık } \\
\text { Ort } \pm \text { SS }\end{array}$ & $\begin{array}{c}\text { Bencillik } \\
\text { Ort } \pm \text { SS }\end{array}$ & $\begin{array}{c}\text { Olumsuz Ruhsal } \\
\text { Durum } \\
\text { Ort } \pm \text { SS }\end{array}$ & $\begin{array}{c}\text { Kariyer Bağlılığı } \\
\text { Ölçeği } \\
\text { Ort } \pm \text { SS }\end{array}$ & $\begin{array}{c}\text { Görev Performans } 1 \\
\text { Ölçeği } \\
\text { Ort } \pm \text { SS }\end{array}$ \\
\hline \multicolumn{8}{|l|}{ Cinsiyet } \\
\hline Kadın (55) & $54,76 \pm 17,87$ & $19,29 \pm 7,04$ & $14,33 \pm 5,26$ & $11,15 \pm 4,39$ & $10,00 \pm 5,15$ & $\mathbf{5 2 , 7 3} \pm 8,84$ & $14,98 \pm 5,19$ \\
\hline Erkek (47) & $57,23 \pm 21,45$ & $19,81 \pm 8,85$ & $15,89 \pm 7,66$ & $11,57 \pm 4,38$ & $9,96 \pm 4,47$ & $\mathbf{5 6 , 9 1} \pm 8,02$ & $15,74 \pm 3,48$ \\
\hline$t / p$ &,$- 626 /, 533$ &,$- 323 /, 748$ & $-1,217 /, 227$ &,$- 492 /, 624$ & ,045/, 965 & $-2,506 /, \mathbf{0 1 4}$ &,$- 855 /, 395$ \\
\hline \multicolumn{8}{|l|}{ Medeni Durum } \\
\hline Evli (32) & $55,72 \pm 21,04$ & $19,66 \pm 8,72$ & $15,19 \pm 7,28$ & $11,06 \pm 4,24$ & $9,81 \pm 4,83$ & $54,94 \pm 8,81$ & $15,63 \pm 4,12$ \\
\hline Bekâr (70) & $55,99 \pm 18,97$ & $19,47 \pm 7,55$ & $14,99 \pm 6,16$ & $11,47 \pm 4,45$ & $10,06 \pm 4,86$ & $54,53 \pm 8,69$ & $15,20 \pm 4,66$ \\
\hline$t / p$ &,$- 061 /, 951$ & ,103/,918 & ,136/,892 &,$- 445 /, 658$ &,$- 237 /, 814$ & ,218/, 828 & ,463/, 645 \\
\hline
\end{tabular}

Selçuk Üniversitesi Sosyal Bilimler Meslek Yüksekokulu Dergisi, Yıl: 2021 Cilt: 24 Sayı:1 